\title{
Publications of A. H. Black
}

\section{Papers}

Brown, R., Black, A. H., \& Horowitz, A. Phonetic symbolism in natural languages. Journal of Abnormal and Social Psychology, 1955, 50, 388-393. [Reprinted in R. Brown (Ed.), Psycholinguistics. New York: Free Press, 1970. Reprinted in I. Al-Issa \& W. Dennis (Eds.), Cross cultural studies of behavior. New York: Holt, Rinehart \& Winston, 1970.]

Black, A. H., \& Solomon, R. L. A method for continuously measuring the position of a rat in a runway. American Journal of Psychology, 1956, 69, 296-299.

Church, R. M., \& Black, A. H. Latency of the conditioned heart rate as a function of the CS-US interval. Journal of Comparative and Physiological Psychology, 1958, 51, 478-482.

BLACK, A. H. The extinction of avoidance responses under curare. Journal of Comparative and Physiological Psychology, 1958, 51, 519-524.

Carlson, N. J., \& Black, A. H. Traumatic avoidance learning: Note on the effect of response prevention during extinction. Psychological Reports, 1959, 5, 409-412.'

Black, A. H., \& CARlson, N. J. Traumatic avoidance learning: Note on intertrial interval responding. Journal of Comparative and Physiological Psychology, 1959, 52, 759-760.

BLACK, A. H. Heart-rate changes during avoidance learning in dogs. Canadian Journal of Psychology, 1959, 13, 229-242.

Black, A. H., \& CARlson, N. J. Traumatic avoidance learning: The effect of preventing escape responses. Canadian Journal of Psychology, 1960, 14, 21-28.

Black, A. H. Some thoughts on comparative psychology. Ontario Psychological Association Quarterly, June 1960, 13, 33-37.

Black, A. H., \& Morse, P. Avoidance learning in dogs without a warning stimulus. Journal of the Experimental Analysis of Behavior, 1961, 4, 17-23.

Black, A. H., Carlson, N. J., \& Solomon, R. L. Exploratory studies of the conditioning of autonomic responses in curarized dogs. Psychology Monographs, 1962, 76, No. 29.

Black, A. H., \& Annau, Z. Time-out responding during ayoidance conditioning and extinction in the rat. Canadian Journal of Psychology, 1963, 17, 165-173.

BLACK, A. H. The effects of CS-US interval on avoidance conditioning in the rat. Canadian Journal of Psychology, 1963, 17, 174-182.

Kamin, L. J., Brimer, C. J., \& Black, A. H. Conditioned suppression as a monitor of fear of the CS in the course of avoidance training. Journal of Comparative and Physiological Psychology, 1963, 56, 497-501.

Black, A. H., \& LANG, W. H. Cardiac conditioning and skeletal responding in curarized dogs. Psychology Review, 1964, 71, 80-85.

Black, A. H. Cardiac conditioning in curarized dogs: The relationship between heart-rate and skeletal behavior.
In W. F. Prokasy (Ed.), Classical conditioning: $A$ symposium. New York: Appleton-Century-Crofts, 1965.

Black, A. H., \& Dalton, A. J. The relationship between the avoidance response and subsequent changes in heartrate. Acta Biologiae Experimentalis, 1965, 25, 107-119. de Toledo, L., \& Black, A. H. A technique for recording heart-rate in moving rats. Journal of the Experimental Analysis of Behavior, 1965, 8, 281-282.

de Toledo, L., \& Black, A. H. Heart-rate: Changes during conditioned suppression in rats. Science, 1966, 152, 1404-1406.

BLACK, A. H. Transfer following operant conditioning in the curarized dog. Science, 1967, 155, 201-203. (Reprinted in Biofeedback and self-control. Chicago: Aldine Press, 1971.)

de Toledo, L., \& Black, A. H. The effects of preshock on subsequent avoidance conditioning. Journal of Comparative and Physiological Psychology, 1967, 3, 493-499.

Dalton, A., \& Black, A. H. Hippocampal electrical activity during the operant conditioning of movement and refraining from movement. Communications in Behavioral Biology, 1968, 2, 267-273.

Reberg, D., \& Black, A. H. Compound testing of individually conditioned stimuli as an index of excitatory and inhibitory properties. Psychonomic Science, 1969, 17, 30-31.

Dixon, C., De Toledo, L., \& Black, A. H. A technique for recording electromyographic activity in freely-moving rats using an all-purpose slip ring commutator. Journal of the Experimental Analysis of Behavior, 1969, 12, 507-509.

Black, A. H., Young, G. A., \& Batenchuk, C. The avoidance training of hippocampal theta waves in flaxedilized dogs and its relation to skeletal movement. Journal of Comparative and Physiological Psychology, 1970, 70, 15-24. [Reprinted in Biofeedback and selfcontrol (1970 ed.). Chicago: Aldine Press, 1971.]

DE Toledo, L., \& BlACK, A. H. The retention of aversively motivated responses in rats. Journal of Comparative and Physiological Psychology, 1970, 71, 276-282.

Black, A. H. Mediating mechanisms of conditioning. Conditional Reflex, 1970, 5, 140-152.

BLACK, A. H. The direct control of neural processes by reward and punishment. American Scientist, 1971, 59, 236-245. [Reprinted in: (1) Biofeedback and self-control (1971 ed.). Chicago: Aldine Press, 1972. (2) L. Bourne \& B. Ekstrand (Eds.), Principles and meanings of psychology: Readings. Hinsdale, Ill: Dryden Press, in press. (3) G. E. Schwartz, H. Hirari, \& T. Watanabe (Eds.), Readings on biofeedback. Tokyo, Japan: Seishin Shobo, in press.]

Black, A. H. Autonomic aversive conditioning in infrahuman subjects. In R. F. Brush (Ed.), Aversive conditioning and learning. New York: Academic Press, 1971.

BLACK, A. H. The operant conditioning of central nervous system electrical activity. In G. H. Bower (Ed.), The psychology of learning and motivation (Vol. 6). New York: 
Academic Press, 1972. [Reprinted in Biofeedback and self-control annual (1972 ed.). Chicago: Aldine Press, 1973.]

Black, A. H., \& DE Toledo, L. The relationship among classically conditioned responses: Heart rate and skeletal behavior. In A. H. Black \& W. F. Prokasy (Eds.), Classical conditioning II: Current theory and research. New York: Appleton-Century-Crofts, 1972.

Black, A. H., \& Young, G. A. Constraints on the operant conditioning of drinking. In R. M. Gilbert \& J. R. Millenson (Eds.), Reinforcement: Behavioral analyses. New York: Academic Press, 1972.

Black, A. H., \& Young, G. A. The electrical activity of the hippocampus and cortex in dogs operantly trained to move and to hold still. Journal of Comparative and Physiological Psychology, 1972, 79, 128-141.

BLACK, A. H. The operant conditioning of the electrical activity of the brain as a method for controlling neural and mental processes. In J. McGuigan (Ed.), Psychophysiology of thinking. New York: Academic Press, 1973.

BLACK, A. H. Unlearning visceral learning. New Scientist, 1974, 61, 269-270.

Black, A. H. Operant autonomic conditioning: The analysis of response mechanisms. In P. A. Obrist, A. H. Black, J. Brener, L. V. DiCara (Eds.), Contemporary trends in cardiovascular psychophysiology. Chicago: Aldine Press, 1974.

Black, A. H. Summary comments. In P. A. Obrist, A. H. Black, J. Brener, \& L. Dicara (Eds.), Contemporary trends in cardiovascular psychophysiology. Chicago: Aldine Press, 1974.

Bracewell, R. J., \& Black, A. H. The effects of restraint and noncontingent preshock on subsequent escape learning in the rat. Learning and Motivation, 1974, 5, 53-69.

BLACK, A. H. Operant conditioning of CNS electrical activity and the neural basis of learning. In $\mathrm{M}$. $\mathrm{H}$. Chase \& S. Fox (Eds.), Operant control of the electrical activity of the brain. Los Angeles: UCLA Brain Research Institute, 1975.

Nadel, L., O'Keefe, J., \& Black, A. H. Slam on the brakes: A critique of Altman, Brunner and Bayer's response inhibition model of hippocampal function. Behavioral Biology, 1975, 14, 151-162.

BlACK, A. H. Hippocampal electrical activity and behavior. In R. L. Isaacson \& K. H. Pribram (Eds.), The hippocampus (Vol. 2). New York: Plenum, 1975.

Black, A. H., \& CotT, A. Biofeedback: A useful tool in basic research, but its therapeutic value is still unproven. Science Forum, 1976, 9, 11-14.

Morris, R. G. M., Black, A. H., \& O’Keefe, J. Hippocampal EEG during a ballistic movement. Neuroscience Letters, 1976, 3, 102.

Black, A. H., Anchel, H., Barbaree, H., \& Okaiche, $H$. The effect of lesions of the fornix on the behaviour of the rat a deficit in place learning. Neuroscience Letters, 1976, 3, 76-77.

Black, A. H., Сotт, A., \& Pavloski, R. The operant learning theory approach to biofeedback training. In G. E. Schwartz \& J. Beatty (Eds.), Biofeedback: Theory and research. New York: Academic Press, 1977.

Black, A. H., Osborne, B., \& Ristow, W. C. A note on the operant conditioning of autonomic responses. In H. Davis \& H. M. B. Hurwitz (Eds.), Operant-Pavlovian interactions. New York: Erlbaum, 1977.

Black, A. H., \& Сотт, A. A perspective on biofeedback. In J. Beatty (Ed.), Biofeedback and behavior: A NATO symposium. New York: Plenum, 1977.

BLACK, A. H. Comments on "learned helplessness" by Maier and Seligman. Journal of Experimental Psychology: General, 1977, 106, 41-43.

Black, A. H., Nadel, L., \& O'Keefe, J. Hippocampal function in avoidance learning and punishment. Psychological Bulletin, 1977, 84, 1107-1129.

Young, G. A., \& Black, A. H. Constraints on licking as an operant: Comparisons of operant licking and leverpressing for negative and positive reinforcement. Learning and Motivation, 1977, 8, 387-403.

Morris, R. G. M., \& BlACK, A. H. Hippocampal electrical activity and behavior elicited by non-reward. Behavioral Biology, 1978, 22, 524-532.

Osborne, B., \& BlACK, A. H. A detailed analysis of behavior during the transition from acquisition to extinction in rats with fornix lesions. Behavioral Biology, 1978, 23, 271-290.

O’Keefe, J., \& Black, A. H. Single unit and lesion experiments on the sensory inputs to the hippocampal cognitive map. In J. Gray (Ed.), Ciba Foundation Symposium on Functions of the Septo-hippocampal System. London: Ciba Foundation, 1978.

Herrmann, T., Black, A. H., Anchel, H., \& Ellen, P. A comparison of septal and fornical lesioned rats' performance on the Maier three table reasoning problem. Physiology \& Behavior, 1978, 20, 297-302.

Cott, A., Pavloski, R. P., \& Black, A. H. The role of sensorimotor rhythm feedback in the biofeedback treatment of epilepsy: A preliminary report. In N. Birbaumer \& H. D. Kimmel (Eds.), Biofeedback and self-regulation. Hillsdale, N.J: Erlbaum, 1979.

Black, A. H. Functions of the septo-hippocampal system. Nature, 1978, 271, 208-210.

Black, A. H. Comments on "How adaptive behaviour is produced." The Behavioral and Brain Sciences, in press.

Winocur, G., \& Black, A. H. Cue-induced recall of a passive avoidance response by rats with hippocampal lesions. Physiology \& Behavior, 1978, 21, 39-44.

Oкаiche, H., Anchel, H., Barbaree, H., \& Black, A. $\mathrm{H}$. The punishment of runway behavior in rats with fornical lesions. Physiology \& Behavior, 1978, 21, 503-509.

Osborne, B., Sivakumaran, T., \& Black, A. H. Effects of fornix lesions on adrenocortical responses to changes in environmental stimulation. Behavioral Biology, 1979, 25, 227-241. 


\section{Technical Reports}

Black, A. H. A comment on yoked control designs (Tech. Rep. No. 11). Hamilton, Ont: Department of Psychology, McMaster University, September 1967.

BцACK, A. H. Operant conditioning of heart rate under curare (Tech. Rep. No. 12). Hamilton, Ont: Department of Psychology, McMaster University, October 1967.

\section{Books}

Black, A. H., \& Prokasy, W. F. (Eds.). Classical conditioning (Vol. 2) Current theory and research. New York: Appleton-Century-Crofts, 1972.

Obrist, P. A., Black, A. H., Brener, J., \& DiCara, L. V. (Eds.). Contemporary trends in cardiovascular psychophysiology. Chicago: Aldine Press, 1974. 